\title{
Effect of activin on production and secretion of prolactin and growth hormone in cultured rat GH3 cells
}

\author{
Noriko Tamura $^{1}$, Minoru Irahara ${ }^{1}$, Akira Kuwahara ${ }^{1}$, Kenjiro Ushigoe $^{1}$, Hiromu Sugino $^{2}$ and Toshihiro Aono ${ }^{1}$ \\ ${ }^{1}$ Department of Obstetrics and Gynecology, School of Medicine and ${ }^{2}$ Institute for Enzyme Research, University of Tokushima, Tokushima, \\ 770-8503 Japan \\ (Correspondence should be addressed to N Tamura, Department of Obstetrics and Gynecology, University of Tokushima School of Medicine, \\ 3-18-15 Kuramotocho, Tokushima, 770-8503 Japan; Email: noriko@shikoku.ne.jp)
}

\begin{abstract}
Objective: To evaluate the effect of the growth factor activin A on the secretion of prolactin (PRL) and $\mathrm{GH}$ in cultured $\mathrm{GH} 3$ cells.

Methods: The concentrations of PRL and GH secreted from GH3 cells cultured in media with and without activin A were measured by RIA, and the expression of PRL mRNA and GH mRNA were analyzed using the Northern blot method.

Results: Activin A significantly inhibited PRL release from GH3 cells cultured for $48 \mathrm{~h}$ in a dosedependent manner (activin: $0.3-3 \mathrm{nM}$ ). The inhibitory effects of $3 \mathrm{nM}$ activin A were observed in the culture from $12 \mathrm{~h}$ to $48 \mathrm{~h}(53.2 \%$ of control). Activin A $(3 \mathrm{nM})$ also significantly inhibited the expression of PRL mRNA at $24 \mathrm{~h}$ (33.8\% of control). In contrast, activin A significantly stimulated $\mathrm{GH}$ release from $\mathrm{GH} 3$ cells cultured for $48 \mathrm{~h}$ in a dose-dependent manner (activin: $0.3-3 \mathrm{nM}$ ). The stimulatory effect of $3 \mathrm{nM}$ activin A was observed in the culture for $48 \mathrm{~h}(157.6 \%$ of control). Activin A (3nM) also significantly stimulated the expression of GH mRNA at $24 \mathrm{~h}$ (183.6\% of control). In spite of these significant changes in PRL and GH secretion, pit-1 mRNA levels were not significantly changed by activin $A$.

Conclusions: These findings indicated that activin A modulates PRL and GH secretion through the regulation of PRL and GH gene transcription in GH3 cells, but that these effects are unrelated to pit-1 gene expression.
\end{abstract}

European Journal of Endocrinology 142 506-511

\section{Introduction}

Activin is a member of the transforming growth factor $\beta$ (TGF- $\beta$ ) superfamily. Proteins of this superfamily exert potent growth-regulatory effects on their respective target tissues via a family of specific cell surface receptors. Activin mRNAs are expressed in a variety of tissues, including the ovary, testis, placenta, brain, bone marrow, and pituitary (1), and activin receptor (typeIA, typeII and typeIIB) mRNA expression has been reported in the rat $(2,3)$. Effects of activin on cellular proliferation and/or differentiation have also been observed in primary cultured cells and established cell lines (4-6).

Activin was initially isolated from gonadal fluids characterized by their ability to stimulate follicle-stimulating hormone (FSH) secretion from cultured rat pituitary cells $(7,8)$. Moreover, in cultured rat pituitary cells, activin inhibits basal growth hormone $(\mathrm{GH})(7,9$, 10), prolactin (PRL) (11) and adrenocorticotropin (7) secretion. Activin also inhibits thyrotropin-releasing hormone (TRH)-stimulated PRL secretion and GH-releasing factor (GRF)-stimulated GH secretion (12). Activin thus plays important roles in hormone secretion from the pituitary. However, the detailed mechanisms of the regulation of each hormone by activin are not yet clear.

GH3 cells, an established cell line from rat pituitary tumor cells, secrete both PRL and GH (13). It has been shown that $\mathrm{GH} 3$ cells retain their ability to respond to TRH (14), epidermal growth factor (EGF) $(15,16)$ and nerve growth factor (NGF) (17). Recent studies have demonstrated that activin receptors (typeIA, typeII and typeIIB) are present on GH3 cells $(18,19)$. GH3 cells are thus a useful model with which to study the roles of activin in hormone secretion by the pituitary. In this study, we examined the effects of activin A on the production and secretion of PRL and GH in GH3 cells, in order to clarify the process of secretion of these hormones from the pituitary.

\section{Materials and methods}

\section{Cell culture}

Activin A was kindly provided by Dr Y Eto (Central Research Laboratory of Ajinomoto Co. Inc., Japan). The 
GH3 cells were plated into 24-multiwell plates (Nunc Inter Med., Denmark) $\left(2 \times 10^{5}\right.$ cells/well $)$ and cultured in Ham's F10 medium (Gibco, Grand Island, NY, USA) with $15 \%$ horse serum and $2.5 \%$ fetal calf serum and penicillin $(100 \mu \mathrm{g} / \mathrm{ml})$ at $37^{\circ} \mathrm{C}$ under a humidified atmosphere of $5 \% \mathrm{CO}_{2}$ and $95 \% \mathrm{O}_{2}$. After pre-culture for $24 \mathrm{~h}$, each medium was exchanged for medium with various concentrations of activin A. After incubation for various times, the medium was collected and stored at $-40^{\circ} \mathrm{C}$ until assay. In the same fashion, GH3 cells were seeded into $6 \mathrm{~cm}$ dishes (Nunc) at a density of $3 \times 10^{6} /$ dish and incubated in culture medium with activin $\mathrm{A}$ (3.0 nM). After incubation for various times, cells were collected and used for RNA analysis.

\section{Measurement of PRL and GH concentrations}

PRL concentrations in culture medium were determined with a double-antibody RIA kit supplied by the National Pituitary Program, Bethesda, MD, USA. GH levels were measured with a rat $\mathrm{GH}$ assay system purchased from Amersham International plc, Aylesbury, Bucks, UK. Coefficients of intra- and interassay variation were less than $10 \%$ for both PRL and GH assays.

\section{Cloning of rat PRL, GH and pit-1 cDNA}

The partial cDNAs corresponding to rat PRL (434bp), GH (439bp) and the pituitary-specific transcription factor pit-1 (662bp) were subcloned into vectors (pBluescript KS-, Stratagene, La Jolla, CA, USA) by RTPCR. RT-PCR was carried out with rat pituitary mRNA with the following sense primers and antisense primers: GH sense primer 5'-TCGAGCGTGCCTACATTCC-3', GH antisense primer 5'-TTGAGCAGAGC GTCATCG-3', PRL sense primer $5^{\prime}$-TTGACCGTGTGGTCATGC-3', PRL antisense primer $5^{\prime}$-GGATTCTTCATCAACTCCTTGC-3', pit-1 sense primer 5'-CTGAGAATGCACCACAGTGC- $3^{\prime}$ and pit-1 antisense primer $5^{\prime}$-ATGATCTCCTGCGAAGAAGG$3^{\prime}$. Each inserted cDNA was confirmed to correspond to rat PRL, GH or pit-1 by a DNA sequencing method.

\section{RNA extraction and Northern blot analysis}

Total RNA was extracted from cultured cells by the acid guanidinium thiocyanate-phenol-chloroform method (20). Each total RNA $(4 \mu \mathrm{g})$ was electrophoresed in $1 \%$ agarose gel, and transferred to nylon membrane (Hybond-N; Amersham International plc). Prehybridization was performed for $2 \mathrm{~h}$ at $65^{\circ} \mathrm{C}$ in hybridization buffer $(5 \times$ SSC, $50 \%$ formamide, $5 \times$ Denhardt's solution, $0.5 \%$ sodium dodecyl sulfate (SDS), and $0.02 \mathrm{mg} / \mathrm{ml}$ denatured sonicated salmon sperm DNA (Sigma Chemical Co, St Louis, MO, USA). The membranes were hybridized overnight at $65^{\circ} \mathrm{C}$ in exchanged hybridization buffer with $\left[{ }^{32} \mathrm{P}\right]$-labeled DNA probe corresponding to rat PRL, GH or pit-1 cDNA. Probes were obtained with a random primer labeling kit (Rediprime; Amersham International plc) with rat PRL, GH and pit-1 cDNA. After hybridization with each probe, the membranes were washed twice with $2 \times$ SSC plus $0.1 \%$ SDS at $65^{\circ} \mathrm{C}$ for $1 \mathrm{~h}$. After crosslinking by u.v. light, autoradiography was performed at $-80^{\circ} \mathrm{C}$ for $60 \mathrm{~h}$. The membranes were then exposed to imaging plates (Fuji Photo Film Co. Ltd, Tokyo, Japan) for $12-24 \mathrm{~h}$ at room temperature. The relative amounts of the respective mRNAs were detected and
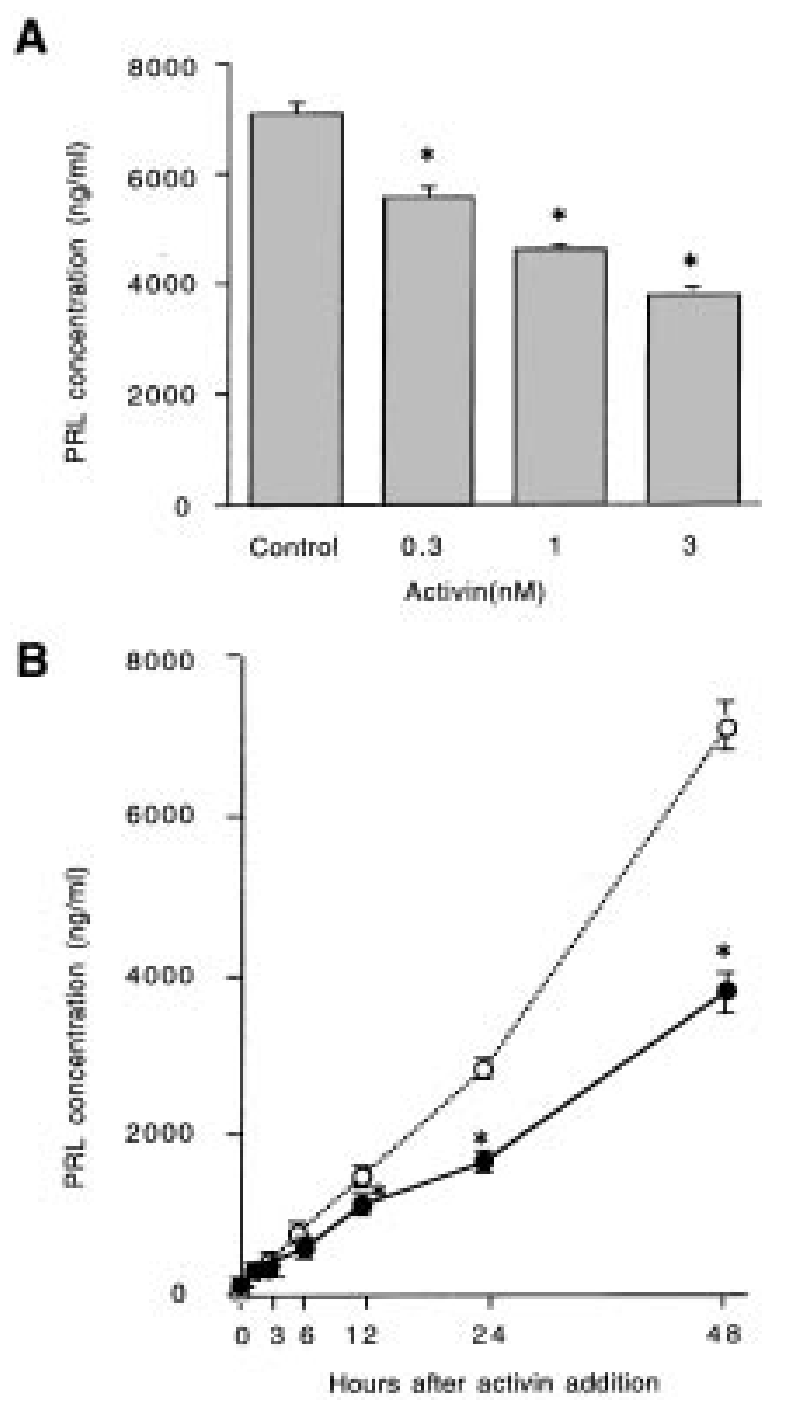

Figure 1 Inhibitory effect of activin A on PRL secretion from cultured GH3 cells. (A) The treatment of GH3 cells for $48 \mathrm{~h}$ with $0-3 \mathrm{nM}$ activin A significantly decreased the basal PRL release in a dosedependent manner $(P<0.01$, ANOVA). Values are means \pm S.E.M. $(n=4) .{ }^{*} P<0.01$ ( $t$-test) compared with control. (B) Time-course study of basal PRL release. Cells were co-cultured with $0 \mathrm{nM}(O)$ or $3 \mathrm{nM}$ activin $\mathrm{A}(\bullet)$ for various time-periods. Treatment with $3 \mathrm{nM}$ activin A significantly inhibited basal PRL secretion from 12 to $48 \mathrm{~h}$. Values are means \pm S.E.M. $(n=4) .{ }^{*} P<0.01$ ( $t$-test) compared with control. 
quantitated using an imaging analyzer (Fuji BAS 2000; Fuji Photo Film Co. Ltd) and expressed as percentages of the time $0 \mathrm{mRNA}$ level.

\section{Data analysis}

Results are presented as means \pm S.E.M. The dose responses for activin addition were determined using ANOVA. For comparison between the two groups, Student's $t$-test was used. Findings of $P<0.05$ were considered significant.

\section{Results}

\section{Effect of activin A on PRL secretion}

Activin A inhibited basal PRL secretion from GH3 cells in a dose-dependent manner (Fig. 1A). PRL concentration in culture medium significantly decreased with the addition of $0.3 \mathrm{nM}$ activin $\mathrm{A}$, and reached $53.2 \%$ of the control level with $3 \mathrm{nM}$ activin. The significant inhibitory effect of activin A (3nM) on PRL secretion was observed in culture from 12 to $48 \mathrm{~h}$ (Fig. 1B).

Figure 2 shows the effect of activin A on PRL mRNA levels in GH3 cells determined by Northern blot analysis. The addition of $3 \mathrm{nM}$ activin A suppressed the expression of PRL mRNA at $12 \mathrm{~h}$ and $24 \mathrm{~h}$, and maximum suppression (33.8\% of control) was observed at $24 \mathrm{~h}$. However, this inhibitory effect was no longer present at $48 \mathrm{~h}$, at which time the expression of PRL mRNA had returned to control level.

\section{Effect of activin A on GH secretion}

Activin A stimulated basal GH secretion from GH3 cells in a dose-dependent manner (Fig. 3A). GH concentration in culture medium significantly increased with the addition of $3 \mathrm{nM}$ activin $\mathrm{A}(157.6 \%$ of control). A stimulatory effect of activin A on $\mathrm{GH}$ secretion was observed in culture for $48 \mathrm{~h}$ (Fig. 3B).

Figure 4 shows the effect of activin A on GH mRNA levels in GH3 cells determined by Northern blot analysis. Major bands corresponding to GH RNA species of 2.3 and $1.0 \mathrm{~kb}$ were found. The $1.0 \mathrm{~kb}$ species is a mature GH mRNA, and the $2.3 \mathrm{~kb}$ species is possibly a $\mathrm{GH}$ precursor RNA. The addition of $3 \mathrm{nM}$ activin A enhanced the expression of GH mRNA, and a significant increase in this expression $(183.6 \%$ of control) was observed at $24 \mathrm{~h}$. However, this stimulatory effect on mRNA tended to decline at $48 \mathrm{~h}$.

\section{Effect of activin A on expression of pit-1 mRNA}

Pit-1 is a pituitary-specific transcription factor regulating the expression of PRL and GH genes. To determine the mechanism of the effect of activin A on PRL and GH secretion from $\mathrm{GH} 3$ cells, the effect of activin A on the expression of pit-1 mRNA in GH3 cells was examined.
A
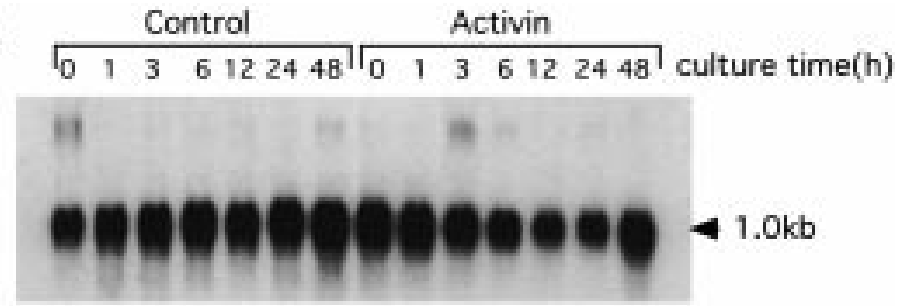

B

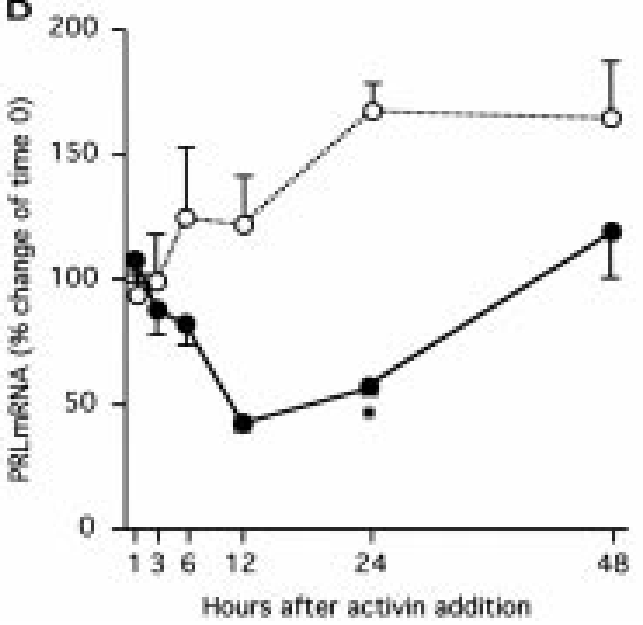

Figure 2 The effect of activin A on the expression of PRL mRNA in cultured GH3 cells. GH3 cells were co-cultured with and without activin $A$ for various time-periods. Total RNA was extracted from cells. Northern blot analysis and quantitation of PRL mRNA was performed. (A) A representative autoradiogram showing the inhibited expression of $P R L$ mRNA in response to activin A: $4 \mu \mathrm{g}$ total RNA was used. (B) Values quantitated from autoradiographic signals using an imaging analyzer are given. Changes in the amount of PRL mRNA with (0) or without $(O)$ activin $A(3 \mathrm{nM})$ are shown. Results are plotted as percentages of the time 0 mRNA levels. Values are means \pm S.E.M. $(n=3) .{ }^{*} P<0.01$ ( $t$-test) compared with control. 

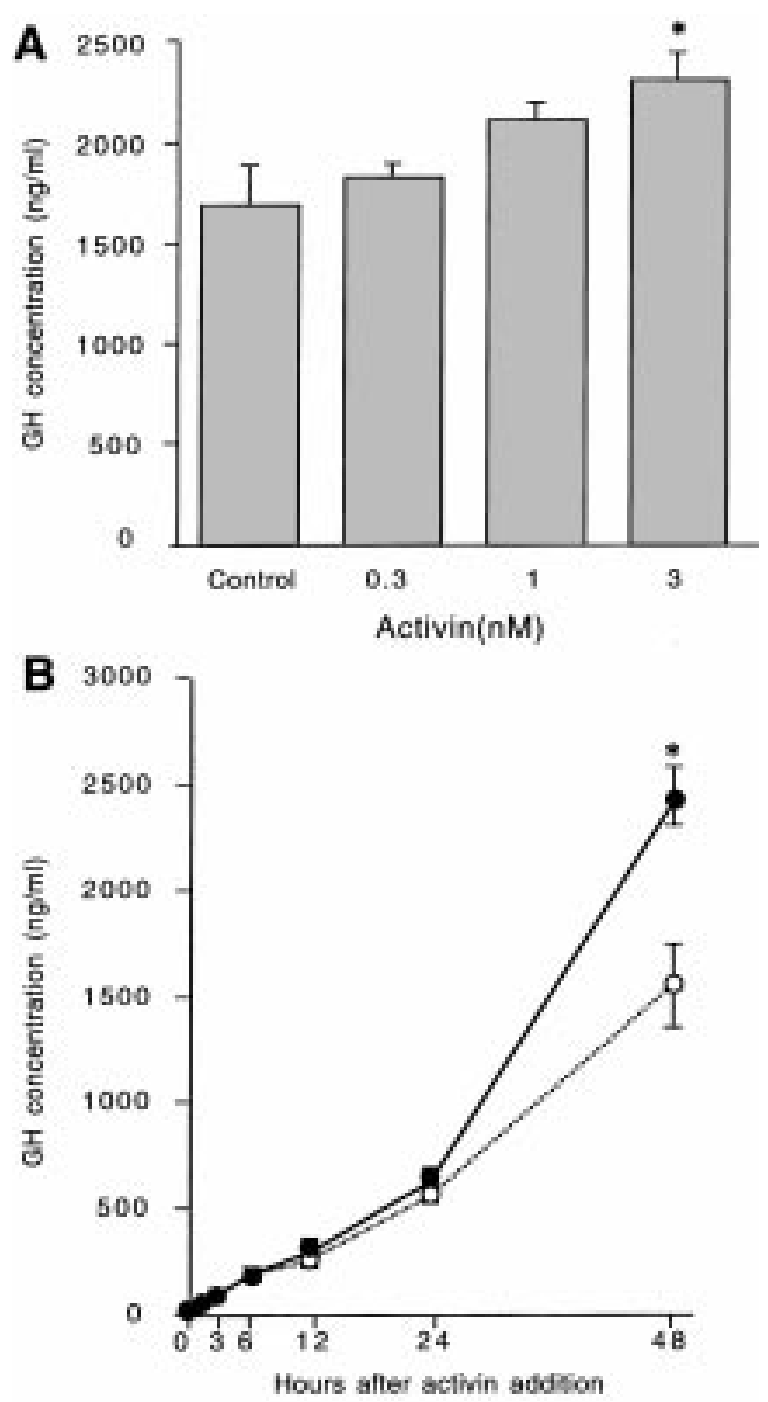

Figure 3 Stimulatory effect of activin A on GH secretion from cultured $\mathrm{GH} 3$ cells. (A) The treatment of $\mathrm{GH} 3$ cells for $48 \mathrm{~h}$ with $0-3 \mathrm{nM}$ activin A significantly stimulated the basal $\mathrm{GH}$ release in a dose-dependent manner $(P<0.05$, ANOVA). Values are means \pm S.E.M. $(n=3)$. ${ }^{*} P<0.05$ (t-test) compared with control. (B) Timecourse study of basal GH release. Cells were co-cultured with $0 \mathrm{nM}$ $(\mathrm{O})$ or $3 \mathrm{nM}$ activin $\mathrm{A}(\bullet)$ for various time-periods. GH secretion was significantly stimulated by activin $\mathrm{A}$ after $48 \mathrm{~h}$ of incubation. Values are means \pm S.E.M. $(n=3)$. ${ }^{*} P<0.05$ (t-test) compared with control.

As shown in Fig. 5, activin A had no significant effect on the expression of pit-1 mRNA in GH3 cells.

\section{Discussion}

In the present study, we demonstrated that activin A stimulated basal GH secretion and inhibited basal PRL secretion in GH3 cells via modulation of the transcription of the GH and PRL genes. Using a rat pituitary monolayer culture system, Billestrup et al. (10) reported that no reduction in $\mathrm{GH}$ biosynthesis was observed after 6-h treatment with activin, but that by $24 \mathrm{~h} \mathrm{GH}$ biosynthesis was clearly inhibited. In our time-course studies, a significant effect of activin on PRL mRNA and $\mathrm{GH}$ mRNA levels also appeared at $24 \mathrm{~h}$ after the start of incubation. In addition, by $48 \mathrm{~h}$, both mRNA levels tended to return to time 0 mRNA levels. The decline of the effect of activin on PRL and GH transcription suggests the existence of a negative regulatory system in GH3 cells. It has been suggested that, in the pituitary, activin plays an autocrine or paracrine role through interaction with follistatin, which has been demonstrated to function as a negative regulator of activin as a result of its ability to bind activin.

Pit-1, a tissue-specific transcription factor, plays an important role in the transcription of the PRL and GH genes in pituitary cells. MacCormick et al. (21) and Supowit et al. (22) demonstrated that repression of both $\mathrm{GH}$ and PRL syntheses by activin in somatic cell hybrids between GH3 cells and mouse LB82 fibroblasts occurred as a result of the suppression of pit-1 expression. However, TGF- $\beta$ was found to inhibit transcription of the PRL gene in GH3 cells, but not that of the GH gene, through a mechanism independent of pit-1 gene expression (23). We also found that pit-1 gene transcript levels in $\mathrm{GH} 3$ cells were not significantly affected by activin. These data do not address the possibility of activin-induced post-translational modifications of the pit-1 protein and interactions with the promoter. Gaddy-Kurten \& Vale (24) demonstrated that activin decreased GH expression in MtTW15 cells through multilevel regulation of pit-1, involving not only a decrease in pit-1 DNA-binding activity but also a decrease in the stability and synthesis of pit-1.

In a pituitary monolayer culture system, activin has been found to be a negative regulator of pituitary somatotrophs and lactotrophs (7, 9-11). In our study, $\mathrm{GH} 3$ cells, which were derived from rat pituitary tumor cells, exhibited a paradoxical GH response to activin. Daniels et al. (25) reported that activin significantly increased basal $\mathrm{GH}$ secretion from cells of two of six human somatotrophinomas in vitro. Similar heterogeneous responses to activin were described in studies of FSH release by human gonadotropin-secreting pituitary tumor cells in vitro (26). These findings suggest that inconsistent and paradoxical responses to activin may also occur in some tumor cells.

GH3 cells are an established cell line which may be related to the bipotential somatomammotroph from which both somatotroph and mammotroph cells derive. It has been reported that differentiation of GH3 cells into mammotroph cells is induced by NGF (17) and EGF (16). In contrast, it has been reported, based on results of fluorescence-activated cell sorting that GRF promotes the differentiation of GH3 cells into somatotroph-like phenotypes (17). The present findings that synthesis of PRL was inhibited and synthesis of $\mathrm{GH}$ was stimulated by activin suggest the possibility that differentiation of the $\mathrm{GH} 3$ cells into somatotrophlike cells may occur. 

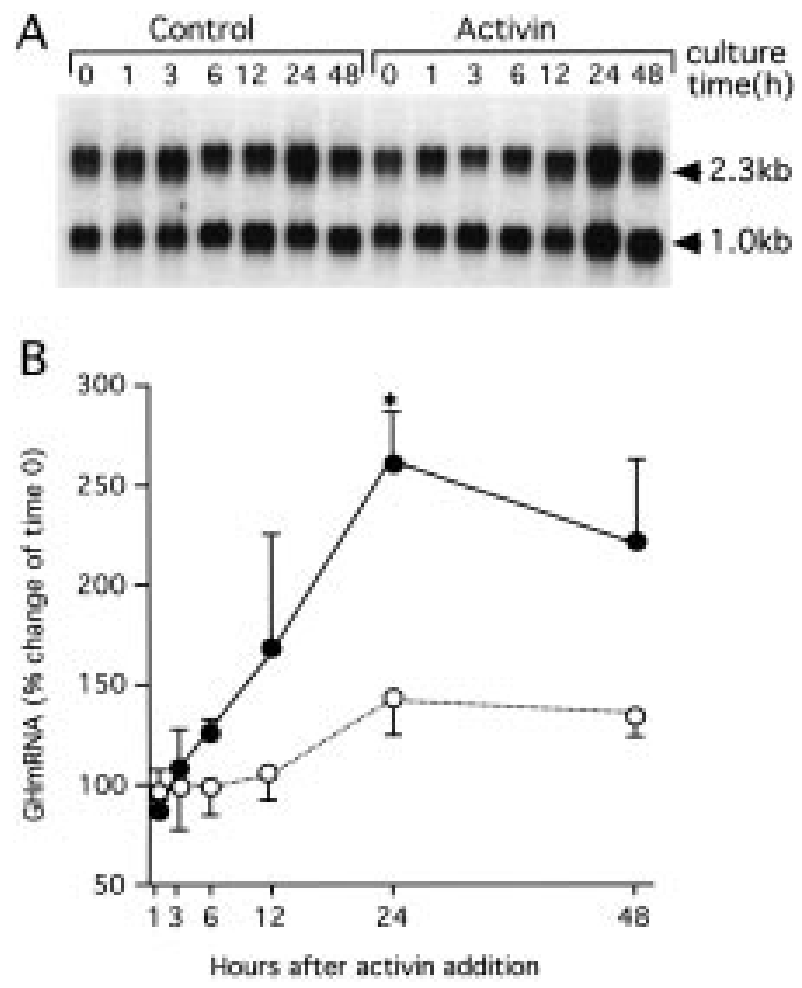

Figure 4 The effect of activin A on expression of GH mRNA in cultured GH3 cells. GH3 cells were co-cultured with and without activin A for various time-periods. Total RNA was extracted from cells. Northern blot analysis and quantitiation of GH mRNA was performed. (A) A representative autoradiogram showing the stimulated expression of GH mRNA in response to activin A. Mature GH mRNA $(1.0 \mathrm{~kb})$ and a possible GH RNA precursor $(2.3 \mathrm{~kb})$ are indicated: $4 \mu \mathrm{g}$ total RNA was used. (B) Values quantitated from autoradiographic signals using an imaging analyzer (only mature GH mRNA) are given. Changes in the amount of GH mRNA with ( or without $(O)$ activin $A(3 \mathrm{nM})$ are shown. Results are plotted as percentages of the time 0 mRNA level. Values are means \pm S.E.M. $(n=3) .{ }^{*} P<0.05$ (t-test) compared with control.

In summary, our study has demonstrated that activin A modulates basal PRL and GH secretion in GH3 cells through the regulation of PRL and GH gene transcription without affecting pit-1 mRNA level.

\section{References}

1 Meunier H, Rivier C, Evans RM \& Vale W. Gonadal and extragonadal expression of inhibin $\alpha, \beta \mathrm{A}$, and $\beta \mathrm{B}$ subunits in various tissues predicts diverse functions. Proceedings of the National Academy of Sciences of the USA 198885 247-251.

2 Aono T, Kuwahara A, Tamura N, Miyamoto S, Ushigoe K, Azuma $\mathrm{K}$ et al. The gene expression of activin receptors in rat pituitary. In Inhibin, Activin and Follistatin, pp 21-27. Eds T Aono, H Sugino \& W Vale. New York: Springer-Verlag, 1997.

3 Cameron VA, Nishimura E, Mathews LS, Lewis KA, Sawchenko PE \& Vale W. Hybridization histochemical localization of activin receptor subtypes in rat brain, pituitary, ovary, and testis. Endocrinology 1994134 799-808.

4 Eto Y, Tsuji T, Takezawa M, Takano S, Yokogawa Y \& Shibai H. Purification and characterization of erythroid differentiation

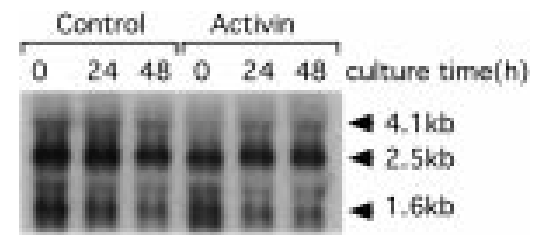

Figure 5 The effect of activin A on expression of pit- 1 mRNA in GH3 cells. Hybridization studies of pit-1 mRNA revealed three bands, one major band and two minor bands. The major band was $2.5 \mathrm{~kb}$, and the minor bands were 4.1 and $1.6 \mathrm{~kb}$. The addition of $3 \mathrm{nM}$ activin $A$ had no significant effect on these bands.

factor (EDF) isolated from human leukemia cell line THP-1. Biochemical and Biophysical Research Communications 1987142 1095-1103.

$5 \mathrm{Yu}$ J, Shao L, Lemas V, Yu AL, Vaughan J, Rivier J et al. Importance of FSH-releasing protein and inhibin in erythrodifferentiation. Nature $1987330765-767$.

6 Gonzalez-Manchon C \& Vale W. Activin-A, inhibin and transforming growth factor- $\beta$ modulate growth of two gonadal cell lines. Endocrinology 1989125 1666-1672.

7 Vale W, River J, Vaughan J, McClintock R, Corrigan A, Woo Wet al. Purification and characterization of an FSH releasing protein from porcine ovarian follicular fluid. Nature $1986321776-$ 779 .

8 Ling N, Ying S-Y, Ueno N, Shimasaki S, Esch F, Hotta M et al. Pituitary FSH is released by a heterodimer of $\beta$-subunits from the two forms of inhibin. Nature 1986321 779-782.

9 Bilezikjian LM, Corrigan AZ \& Vale W. Activin-A modulates growth hormone secretion from cultures of rat anterior pituitary cells. Endocrinology 1990126 2369-2376.

10 Billestrup N, Gonzalez-Manchon C, Potter E \& Vale W. Inhibition of somatotroph growth and growth hormone biosynthesis by activin in vitro. Molecular Endocrinology 19904 356-362.

11 Murata T \& Ying S-Y. Transforming growth factor- $\beta$ and activin inhibit basal secretion of prolactin in a pituitary monolayer culture system. Proceedings of the Society for Experimental Biology and Medicine 1991198 599-605.

12 Kitaoka M, Kojima I \& Ogata E. Activin-A: a modulator of multiple types of anterior pituitary cells. Biochemical and Biophysical Research Communications 1988157 48-54.

13 Tashjian AH Jr, Bancroft FC \& Levine L. Production of both prolactin and growth hormone by clonal strains of rat pituitary tumor cells. Journal of Cell Biology 197047 61-70.

14 Yajima Y \& Saito T. The effects of hypothalamic extracts and TRH on growth hormone production of GH3 cells in culture. Acta Endocrinologica $1983104287-294$.

15 Zhang K, Kulig E, Jin L \& Lloid RV. Effects of estrogen and epidermal growth factor on prolactin and pit-1 mRNA in GH3 cells. Proceedings of the Society for Experimental Biology and Medicine 1993202 193-200.

16 Missale C, Castelletti L, Boroni F, Memo M \& Spano P. Epidermal growth factor induces the functional expression of dopamine receptors in the GH3 cell line. Endocrinology 1991128 13-20.

17 Missale C, Boroni F, Sigala S, Zanellato A, Toso RD, Balsari A et al. Nerve growth factor directs differentiation of the biopotential cell line GH-3 into the mammotroph phenotype. Endocrinology 1994 135 290-298.

18 Yamashita H, Okadome T, Franzen P, Dijke PT, Heldin C-H \& Miyazono K. A rat pituitary tumor cell line $\left(\mathrm{GH}_{3}\right)$ expresses type I and type II receptors and other cell surface binding protein(s) for transforming growth factor- $\beta$. Journal of Biological Chemistry $1995270770-774$.

19 Moustakas A, Takumi T, Lin HY \& Lodish HF. GH3 pituitary tumor cells contain heteromeric type I and type II receptor complexes for transforming growth factor- $\beta$ and activin-A. Journal of Biological Chemistry 1995270 765-769. 
20 Chomczynski P \& Sacchi N. Single-step method of RNA isolation by acid guanidium thiocyanate-phenol-chloroform extraction. Analytical Biochemistry 1987162 156-159.

21 MacComick A, Wu D, Castrillo JL, Dana S, Strobl J, Thompson EB et al. Extinction of growth hormone expression in somatic cell hybrids involves repression of the specific trans-activator GHF-1. Cell 198855 379-389.

22 Supowit SC, Ramsey T \& Thompson EB. Extinction of prolactin gene expression in somatic cell hybrids is correlated with the repression of the pituitary-specific trans-activator GHF-1/Pit-1. Molecular Endocrinology 19926 786-792.

23 Delidow BC, Billis WM, Agarwal P \& White BA. Inhibition of prolactin gene transcription by transforming growth factor- $\beta$ in $\mathrm{GH}_{3}$ cells. Molecular Endocrinology 19915 1716-1722.

24 Gaddy-Kurten D \& Vale W. Activin increases phosphorylation and decreases stability of the transcription factor pit-1 in MtTW15 somatotrope cells. Journal of Biological Chemistry 1995270 28733-28739.

25 Daniels M, Harris PE, James RA, Turner SJ, Dewar JH \& KendallTaylor P. Effect of recombinant human activin A on growth hormone secretion by human somatotrophinomas in vitro. Journal of Endocrinology 1993137 329-334.

26 Alexander JM, Jameson JL, Bikkal HA, Schwall RH \& Klibanski A. The effects of activin on follicle-stimulating hormone secretion and biosynthesis in human glycoprotein hormone-producing pituitary adenomas. Journal of Clinical Endocrinology and Metabolism 199172 1261-1267.

Received 21 July 1999

Accepted 3 December 1999 